\title{
Iron speciation in the Wufeng- Longmaxi black shale of Sichuan Basin: redox conditions and beyonds
}

\author{
YUNPENG WANG ${ }^{1}$, SHUYONG SHI ${ }^{1}$, YIJUN ZHENG ${ }^{1}$, \\ YuHONGLiaO $^{1}$, XiAngXian MA ${ }^{2}$, GUODONGZHENG ${ }^{2}$ \\ ${ }^{1}$ SKLOG, Guangzhou Institute of Geochemistry, CAS, \\ Guangzhou 510640, China, wangyp@gig.ac.cn \\ ${ }^{2}$ Northwest Institute of Eco-Environment and Resources, \\ CAS, Lanzhou 730000, China
}

Wufeng-Longmaxi black shale in Sichuan Basin is the main shale gas produing strata. The redox condition and organic matter (OM) perservation varies extensively in vertical and coverage scales. We analyzed iron species of core shale samples from Wufeng $\left(\mathrm{O}_{3 \mathrm{w}}\right)$, Guangyingqiao $\left(\mathrm{O}_{3 \mathrm{~g}}\right)$ and Longmaxi $\left(\mathrm{S}_{11}\right)$ formations of 7 boreholes using Mössbauer spectrometry. Four iron species were indentified: pyrite- $\mathrm{Fe}^{2+}$, clay associated para- $\mathrm{Fe}^{2+}$, carbonate associated para- $\mathrm{Fe}^{2+}$, and transition state $\mathrm{Fe}^{2+} \cdot \mathrm{Fe}^{3+}$ (Fig. 1). Pyrite- $\mathrm{Fe}^{2+}$ was common recognized in three layers reflecting a general reduction condition, the relative contents of pyrite- $-\mathrm{Fe}^{2+}$ were $58.4 \%$, $64.5 \%$ and $58.9 \%$ for Wufeng, Guangyingqiao and Longmaxi shale, respectively, while para- $\mathrm{Fe}^{2+}$ associated with illite, chlorite and montmorillonite were $35.9 \%$ for Wufeng and $40.13 \%$ for Longmaxi. Guangyiqiao formation is mainly composed of carbonate, and para- $\mathrm{Fe}^{2} \mathrm{w}$ as mainly associated with Ankerite, Siderite and Fe-calcite, which can be identified in Mössbauer spectra $\left(\mathrm{carb}-\mathrm{Fe}^{2+}\right)$ as its doublet peaks enjoyed two shoulders and were narrower than routine para- $\mathrm{Fe}^{2+}$. Transition state $\mathrm{Fe}^{2+} \cdot \mathrm{Fe}^{3+}$ was also recognized in Guangyiqiao formation, which represented a deposional environment change from reduction to oxidation. This phenomina, representing a local and short term uncompleted environmental changes, was only found in the southern margins of the basin, where TOC was reletively low and OM was not trich and well perserved.

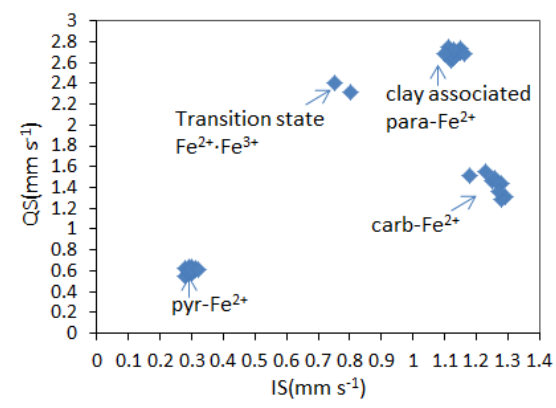

Fig.1 Plot of IS-QS from Mössbauer spectra of core shale samples of different layers, Sichuan Basin 